\title{
Binding of $\mathrm{Hg}$ by bacterial extracellular polysaccharide: a possible role in $\mathrm{Hg}$ tolerance
}

\author{
Cruz Kimberly ${ }^{1,2}$, Guézennec Jean ${ }^{3,4}$, Barkay Tamar ${ }^{1,{ }^{*}}$
}

${ }^{1}$ Department of Biochemistry and MicrobiologyRutgers UniversityNew Brunswick,USA

${ }^{2}$ Department of Biochemistry and Molecular BiologyRutgers Robert Wood Johnson Medical SchoolPiscataway,USA

${ }^{3}$ Ifremer, Centre de BrestPlouzané,France

${ }^{4}$ AiMB (Advices in Marine Biotechnology)Plouzané,France

* Corresponding author : Tamar Barkay, email address : barkay@aesop.rutgers.edu

\begin{abstract}
:
Bacteria employ adaptive mechanisms of mercury $(\mathrm{Hg})$ tolerance to survive in environments containing elevated $\mathrm{Hg}$ concentrations. The potential of extracellular polysaccharides (EPS) production by bacteria as a mechanism of $\mathrm{Hg}$ tolerance has not been previously investigated. The objectives of this study were to determine if bacterial EPS sorb $\mathrm{Hg}$, and if so does sorption provide protection against $\mathrm{Hg}$ toxicity. Purified EPS with different chemical compositions produced by bacterial isolates from microbial mats in French Polynesian atolls and deep-sea hydrothermal vents were assessed for $\mathrm{Hg}$ sorption. The data showed that EPS sorbed up to $82 \%$ of $\mathrm{Hg}$ from solution, that this sorption was dependent on EPS composition, and that sorption was a saturable mechanism. Hg uptake capacities ranged from 0.005 to $0.454 \mathrm{mmol} \mathrm{Hg} / \mathrm{g}$ for the different EPS. To determine if EPS production could alter bacterial $\mathrm{Hg}$ tolerance, Escherichia coli K-12 strains and their EPS defective mutants were tested by the disc inhibition assay. Mercury inhibited growth in a dose-dependent manner with wild-type strains having smaller $(\sim 1 \mathrm{~mm})$, but statistically significant, zones of inhibition than various mutants and this difference was related to a 2 -fold decline in the amount of EPS produced by the mutants relative to cell biomass. These experiments identified colanic acid and hexosamine as Hg-binding moieties in EPS. Together these data indicate that binding of $\mathrm{Hg}$ to EPS affords a low level of resistance to the producing bacteria.
\end{abstract}

Keywords : Mercury, Bacteria, Sorption, Tolerance, Exocellular polysaccharides 


\section{INTRODUCTION}

Mercury $(\mathrm{Hg})^{1}$ is one of the most toxic metals in the environment with no known biological function and is a human and wildlife health hazard (ATSDR 1999; Clarkson 1998; Mann 1990; Onsanit and Wang 2011; Wiatrowski et al. 2006). Since Hg is an element, it cannot be degraded and removed from the environment; it can only be transformed or sequestered to reduce bioavailability. Major sources of $\mathrm{Hg}$ to the environment are emissions of volatile inorganic $\mathrm{Hg}$ from power generating plants (Clarkson and Magos 2006; Lin et al. 2012). Once in the atmosphere, $\mathrm{Hg}$ enters a complex cycle of transformations and transport through the environment.

Transformations between redox states and between inorganic and organic forms of $\mathrm{Hg}$ are due in part to activities of microorganisms. Microbes have been shown to methylate, demethylate, reduce, and oxidize $\mathrm{Hg}$ and these chemical alterations affect $\mathrm{Hg}$ mobility and bioavailability in the environment. Therefore, understanding mechanisms by which microorganisms interact with $\mathrm{Hg}$ can provide a way to modulate the bioavailability, and thus toxicity, of $\mathrm{Hg}$. Mechanisms of $\mathrm{Hg}$ tolerance involving intracellular or extracellular sequestration could be exploited for the bioremediation of contaminated sites to remove Hg from the environment (Clarkson 1998; Clarkson and Magos 2006; Lin et al. 2012; Mann 1990).

Exocellular polysaccharides (EPS) are high molecular weight sugar polymers excreted outside of the cell. They can either be completely disassociated from the cell and released into the surrounding environment or remain associated with the cell

\footnotetext{
${ }^{1}$ Throughout this paper the term mercury $(\mathrm{Hg})$ is used to generally describe the metal. When specific chemical forms of $\mathrm{Hg}$ are considered these are indicated as $\mathrm{Hg}$ (II) relating to ionic $\mathrm{Hg}$ or $\mathrm{Hg}(0)$ relating to elemental $\mathrm{Hg}$.
} 
surface (Dueñas-Chasco et al. 1998; Nichols et al. 2005; Sutherland 1990; Vincent et al. 1994). They form a protective barrier from changes in environmental conditions (Danese et al. 2000; Kazy et al. 2002; Kiliç and Dönmez 2008; Nichols et al. 2005; Sutherland 1990). It is widely known that EPS produced by bacteria, fungi, and algae bind heavy metals preventing their entry into the cell and associated damage (Bozzi et al. 1996; François et al. 2012; Kazy et al. 2002; Kiliç and Dönmez 2008; Macaskie and Dean 1990). The application of EPS for the bioremediation of heavy metal contaminated sites has received considerable attention in the past couple of decades as an ecofriendly and cost effective method for metal removal (François et al. 2012; Kazy et al. 2002; Kiliç and Dönmez 2008; Loaëc et al. 1998; Moppert et al. 2009). The ability and degree to which an EPS will bind a metal cation depends on the chemical composition of the polymer and properties of the metal (Guézennec et al. 2011; Kazy et al. 2002; Moppert et al. 2009). Very few EPS have been studied for their ability to bind $\mathrm{Hg}$ with only a couple papers on $\mathrm{Hg}$ binding to microbial EPS published to date (François et al. 2012; Freire-Nordi et al. 2005).

In this paper, the ability of purified EPS with different chemical compositions to sorb $\mathrm{Hg}$ and $\mathrm{Hg}$ tolerance levels of $E$. coli $\mathrm{K}-12$ strains with altered EPS production were assessed to examine binding of $\mathrm{Hg}$ by bacterial EPS and its role in $\mathrm{Hg}$ tolerance.

\section{MATERIALS AND METHODS}

Exocellular (or exo) Polysaccharides. Previously purified EPS, 4 from bacterial cultures isolated from microbial mats in French Polynesian atolls (Guézennec et al. 2011) and 3 that were purified from deep-sea hydrothermal isolates (Raguénès et 
al. 2003; Rougeaux et al. 1999; Vincent et al. 1994), were included in the study. The EPS varied in their size and chemical composition (Table 1) representing a range of ligands that might differently affect $\mathrm{Hg}$ binding. The EPS vary in their content of ionisable functional groups such as carboxyl, amine, sulfate and to a lesser extent hydroxyl groups that enable these biopolymers to bind heavy metals.

Mercury binding experiments. $\mathrm{Hg}(\mathrm{II})$ binding experiments were performed following the protocol described in Loaëc et al. (1997). Mercuric chloride concentrations ranged from 0.1 to 1,000 milligrams per liter EPS solution. Binding assays were carried out as described by Loaec et al., (1997) except that pre-wetted 3 kDa Millipore Ultracell low binding regenerated cellulose membrane (Amicon Ultra- 0.5, EMD Millipore Billerica, MA) were used to separate EPS-bound from unbound Hg(II) (Loaëc et al. 1997). Controls included EPS solution with $0 \mathrm{mg} / \mathrm{l} \mathrm{Hg}$ and $\mathrm{Hg}$ solution containing no EPS. Samples of EPS-Hg solution were taken for $\mathrm{Hg}$ analysis before and after filtration. For the experiments to examine the nature of $\mathrm{Hg}$ sorption to EPS, there was an additional step of moving the filter to a new microcentrifuge tube following filtration and passing of $0.5 \mathrm{~mL}$ of washing solutions at various $\mathrm{pH}$ 's through the filter. Samples of the wash after filtration were analyzed for the amount of $\mathrm{Hg}$ that was removed by the washing step. The pH's of the washing solutions were 4.0 (buffered by potassium acid phthalate, purchased as a 4x buffer concentrate from Fisher Scientific), 6.92 (ultra pure water, unbuffered), and 9.0 (buffered by $0.5 \mathrm{M} \mathrm{N}$-cyclohexyl-2-aminoethanesulfonic acid [CHES]). Filters were stored frozen $\left(-20^{\circ} \mathrm{C}\right)$ until analysis.

Mercury analysis. All samples, including aqueous samples and thawed filters, were digested by oxidization with $0.2 \mathrm{~N}$ bromine monochloride overnight at room 
temperature. $\mathrm{Hg}$ concentrations were determined by a Hydra AA Automated $\mathrm{Hg}$ Analysis cold vapor atomic adsorption spectrophotometer (CVAAS) as recommend by the manufacturer (Leeman Labs, Inc., Hudson, NH). Experiments were performed in triplicate.

Mercury binding calculations. The Hg uptake capacity (mmol/g EPS) for each EPS was determined using the saturation equation (Dada et al. 2012; de la Rosa et al. 2008; Volesky 1990):

$\mathrm{Hg}$ uptake capacity $=\left(\left[\mathrm{Hg}_{\mathrm{i}}-\mathrm{Hg}_{\mathrm{f}}\right] \times \mathrm{V}\right) \div \mathrm{m}$ where $\mathrm{Hg}_{i}$ was the initial $\mathrm{Hg}$ concentration and $\mathrm{Hg}_{\mathfrak{f}}$ was the concentration of $\mathrm{Hg}$ in the filtrate or free/ unbound $\mathrm{Hg}, \mathrm{V}$ was the volume of the filtered solution, and $\mathrm{m}$ was the mass of the EPS. The logarithmic regression function in Excel ${ }^{\circledR}$ (Microsoft $^{\circledR}$ for Mac 2011 version 14.7.1) was used to fit saturation curve lines.

In addition, $\mathrm{Hg}$ binding was evaluated as percent $\mathrm{Hg}$ removed from solution relative to the no EPS control. Statistical analysis was performed using a 2-way ANOVA with GraphPad Prism 5.04 for Windows software with a Bonferroni post hoc test. Overall alpha was set to 0.05 .

Percent removal of $\mathrm{Hg}$ mass from EPS by washing $(R)$ was determined by using the equation:

$$
R=\left(H_{W} \div H_{E}\right) \times 100
$$

where $\mathrm{Hg}_{\mathrm{w}}$ is the $\mathrm{Hg}$ mass found in the washing filtrate and $\mathrm{Hg}_{\mathrm{E}}$ is the $\mathrm{Hg}$ mass sorbed to EPS. Statisitcal analysis was performed using a 2-way ANOVA with VassarStats (http://vassarstats.net). Overall alpha was set to 0.05 . 
Bacterial strains and growth conditions. Escherichia coli K-12 strain ZK2686 (W3110 $\Delta[$ argF-lac]U169) and its wcaF mutant strain ZK2687 (ZK2686 wcaF31::cam) with a reduced EPS production (Danese et al. 2000) were generously provided by Dr. Kolter (Harvard Medical School). E. coli K-12 strains with altered production of colanic acid and/or hexosamine-rich EPS (Wang et al. 2004) were generously provided by Dr. Romeo (University of Florida). These included strains MG1655( $\left.\mathrm{F}^{-} \lambda^{-}\right)$, TRMG1655(MG1655 csrA::kan), DJ4(TRMG1655 cpsE::Tn10), and TRXWMG $\Delta \mathrm{C}(\mathrm{TRMG} 1655 \Delta p g a C)$.

E. coli strains were grown in media supplemented with antibiotics at $25 \mu \mathrm{g} / \mathrm{ml}$ for chloramphenicol and $100 \mu \mathrm{g} / \mathrm{ml}$ for kanamycin. Media used to grow the E. coli strains were Luria-Bertani agar (LB) plates and a modified M9 medium (MM9) prepared by mixing the following sterile stock solutions and bringing the volume to $1 \mathrm{~L}$ with ultrapure water: $200 \mathrm{~mL}$ of $5 x$ salt solution $\left(\mathrm{NaCl}(2.5 \mathrm{~g} / \mathrm{L}), \mathrm{NH}_{4} \mathrm{Cl}(5 \mathrm{~g} / \mathrm{L})\right.$, and $\mathrm{K}_{2} \mathrm{HPO}_{4}(11.5 \mathrm{~g} / \mathrm{L})$ ), $34 \mathrm{~mL}$ of $10 \mathrm{mg} / \mathrm{mL}$ thiamine, $20 \mathrm{~mL}$ of $20 \%$ casamino acids , $2 \mathrm{~mL} 1 \mathrm{M} \mathrm{MgSO}_{4} \cdot 7 \mathrm{H}_{2} \mathrm{O}$, $0.1 \mathrm{~mL} 1 \mathrm{M} \mathrm{CaCl}_{2} \cdot 2 \mathrm{H}_{2} \mathrm{O}, 25 \mathrm{~mL} 0.335 \mathrm{~g} / \mathrm{mL}$ 3-morpholinopropane-1-sulfonic acid, $2 \mathrm{~mL}$ $500 \mathrm{mM} \mathrm{L}$-arginine, and $4 \mathrm{~mL} 100 \%$ glycerol. All strains were incubated at $37^{\circ} \mathrm{C}$ for all experiments. Frozen stocks of the cultures were created in $20 \%$ glycerol and stored at $80^{\circ} \mathrm{C}$.

Disc inhibition test for $\mathrm{Hg}$ tolerance. Disc inhibition tests were performed using a modified protocol described by Barkay et al. (1990). E. coli strains were grown from frozen stocks on LB agar plates before transfer to MM9. Cultures were subsequently diluted 1:20 into fresh MM9 medium, grown to the beginning of exponential phase, and then centrifuged for 10 minutes at 10,000 $\mathrm{g}$. The supernatants were discarded, and 
the pellets were re-suspended in cold $0.85 \% \mathrm{NaCl}$ solution. $0.1 \mathrm{~mL}$ of which was spread-plated on MM9 plates (2\% agar). After inoculation, the plates were dried in a laminar flow hood before a sterile filter disc was placed on the center of each plate. Filter discs were impregnated with $10 \mu \mathrm{L}$ of $\mathrm{Hg}$ stock with a final mass of $\mathrm{Hg}$ ranging from 0 to 1,000 nmoles and each mass was tested in triplicate. Plates were incubated for 24 hours following which zones of inhibition were measured by placing plates under a dissecting microscope and measuring the distance from the center of the filter disc to the edge of growth. Each zone of inhibition was measured four times at each quadrant of the circle of no growth formed around the filter. A 2-way ANOVA was used for statistical analysis using GraphPad Prism 5.04 for Windows software with an overall alpha set to 0.05 .

EPS production by $E$. coli K-12 strains. Cultures were grown from frozen stock in liquid MM9 medium. The cultures were subsequently diluted 1:100 dilution into fresh liquid MM9, grown to the beginning of exponential phase, before centrifugation for 10 minutes at 10,000 $\mathrm{g}$. The supernatants were discarded, and pellets suspended in $0.85 \%$ sterile saline solution. MM9 plates were dried in a laminar flow hood before 0.1 $\mathrm{ml}$ of culture were spread onto the surface of each. The plates were incubated for 16 hours before biomass was harvested from the plates' surface into sterile saline solution, and centrifuged for 10 minutes at $10,000 \times \mathrm{g}$. The supernatant was collected and frozen at $-20 \stackrel{\circ}{ } \mathrm{C}$ until EPS analysis could be performed. The pellets were washed twice with sterile saline solution. The first washes were collected and frozen at $-20^{\circ} \mathrm{C}$. The remaining cell pellets were frozen at $-20 \stackrel{\circ}{ } \mathrm{C}$ until protein content could be determined. 
EPS production was determined using a modified phenol sulfuric acid assay for sugar determination (DuBois et al. 1956). After the addition of $80 \%$ phenol $(0.025 \mathrm{ml} / 1$ $\mathrm{ml}$ sample or $2.5 \% \mathrm{v} / \mathrm{v})$ and concentrated sulfuric acid $(250 \% \mathrm{v} / \mathrm{v})$, the samples were cooled for 10 minutes at room temperature before optical density was measured with a spectrophotometer at 490 nanometers. D-glucose was used to generate a calibration curve and treated in the same manner as the samples. EPS production was normalized to protein content of the pellet.

Protein content of the pellet was determined by the BioRad microassay for protein determination following the protocol outlined by the manufacturer. Optical density values were read at $595 \mathrm{~nm}$ on a Sunrise remote by Tecan plate reader (Männedorf, Switzerland). The pellets were prepared for the microassay by resuspending in buffer composed of: $16 \mathrm{mM} \mathrm{Na}_{2} \mathrm{HPO}_{4}, 3.8 \mathrm{mM} \mathrm{NaH}_{2} \mathrm{PO}_{4}, 0.5 \mu \mathrm{M}$ EDTA, and $0.0001 \% \beta$ - mercaptoethanol. The samples were boiled for 20 minutes and allowed to completely cool before the BioRad microsassay was performed. Bovine serum albumin (BSA) was used to create the calibration curve and prepared for spectrophotometry in the identical manner as the samples. A student's t-test was performed for statistical analysis with an alpha set to 0.05 and $n=3$ for all samples.

\section{RESULTS}

Sorption of $\mathrm{Hg}$ by EPS. A preliminary experiment tested whether the employed filters (i) contained $\mathrm{Hg}$ that could contaminate experimental EPS solutions, or (ii) could bind $\mathrm{Hg}$ from test solutions. No $\mathrm{Hg}$ could be detected in the filtrate or filter when EPS 
solutions of Mo 203 with $0 \mathrm{mg} / \mathrm{l} \mathrm{Hg}$ were tested, indicating the filtration system did not contain $\mathrm{Hg}$ (Figure S1). When $100 \mathrm{mg} / \mathrm{L} \mathrm{Hg}$ stock solution without EPS was passed through filters, only $3.6 \%$ of the $\mathrm{Hg}$ was bound to filters indicating that $\mathrm{Hg}$ did not readily sorb to the filter material. When $100 \mathrm{mg} / \mathrm{L} \mathrm{Hg}$ stock solution with EPS was passed through filters, $69 \%$ of the $\mathrm{Hg}$ was bound to filters suggesting that $\mathrm{Hg}$ is sorbed to EPS preventing it from passing through the filter. In these experiments, a mass balance was always achieved recovering from $100 \%$ to $119 \%$ of the initially added $\mathrm{Hg}$. Similar experiments were performed at lower concentrations of $\mathrm{Hg}$ with similar results (data not shown). Based on these results (Figure S1), filters were not analyzed for bound $\mathrm{Hg}$ in subsequent experiments; rather EPS-bound $\mathrm{Hg}$ was calculated by subtracting filtered $\mathrm{Hg}$ concentrations from those of the starting solution; filters were stored at $-20{ }^{\circ} \mathrm{C}$ in case needed in the future.

Percent removal of $\mathrm{Hg}$ from solution was first determined at increasing initial $\mathrm{Hg}$ concentrations, 10 to $400 \mathrm{mg} / \mathrm{L}$ (Loaëc et al. 1997), to assess the efficiency of $\mathrm{Hg}$ sorption by each EPS. All four EPS sorbed $\mathrm{Hg}$ to varying degrees but with clear differences (Figure S2). Mo 245 was the most efficient, removing the highest percentage of $\mathrm{Hg}$ at all concentrations tested. RA 19 and Mo 203 behaved similarly to each other, and representing an intermediate efficiency of $\mathrm{Hg}$ binding. In contrast to the other three EPS, GG, an entirely neutral EPS (Table 1) had the lowest efficiency of $\mathrm{Hg}$ binding between $2.2 \%$ and $12.2 \%$ of the added $\mathrm{Hg}$.

Differences in $\mathrm{Hg}$-binding capacities were confirmed by equilibrium sorption isotherms that show distribution of $\mathrm{Hg}$ between solution and EPS versus $\mathrm{Hg}$ concentration at equilibrium and can indicate if binding to EPS is saturable. $\mathrm{As} \mathrm{Hg}$ 
concentration increases so will sorption as long as binding sites are not saturated (Loaëc et al. 1997; Moppert et al. 2009). Equilibrium isotherms indicate for RA 19, Mo 203, and Mo 245, sorption of $\mathrm{Hg}$ to the biopolymer was saturable depicted by a plateau of metal uptake above a certain concentration (Figure 1). Metal uptake by Mo 245 was the highest compared to the other three EPS with values ranging from $0.023 \mathrm{mmol} \mathrm{Hg} / \mathrm{g}$ EPS at initial $\mathrm{Hg}$ concentration of $10 \mathrm{mg} / \mathrm{l}$ to $0.45 \mathrm{mmol} / \mathrm{g}$ at initial concentration of 50 $\mathrm{mg} / \mathrm{l}$. The uptake capacity for Mo 245 was $0.39 \mathrm{mmol} / \mathrm{g}$ and was the highest for all the EPS (Table 2). RA 19 and Mo 203 had similar metal uptake curves with values ranging from $0.023 \mathrm{mmol} / \mathrm{g}$ to $0.197 \mathrm{mmol} / \mathrm{g}$ and $0.020 \mathrm{mmol} / \mathrm{g}$ to $0.198 \mathrm{mmol} / \mathrm{g}$, respectively (Figure 1). The corresponding uptake capacities for RA 19 were $0.247 \pm 0.106 \mathrm{mmol} / \mathrm{g}$ compared to $0.193 \pm 0.026 \mathrm{mmol} / \mathrm{g}$ for Mo 203 (Table 2). This difference was not statistically significant. GG had the lowest metal uptake values (Figure 1), and correspondently, It had the lowest uptake capacity of $0.097 \mathrm{mmol} / \mathrm{g}$ (Table 2). To assess if metal saturation for $\mathrm{GG}$ was reached at $\mathrm{Hg}$ concentration below $10 \mathrm{mg} / \mathrm{l}$, an equilibrium sorption isotherm was obtained at $\mathrm{Hg}$ concentrations of 0.1 to $8 \mathrm{mg} / \mathrm{l}$. The results (data not shown) confirmed that $\mathrm{Hg}$ saturation level for GG was reached at about 10 to $20 \mathrm{mg} / \mathrm{l}$. The $\mathrm{Hg}$ binding capacities of EPS that were obtained from deep-sea vent bacteria were at a similar range to those of the microbial mat strains with HE 800, HYD1545, and MS 907 binding $0.367 \pm 0.035,0.199 \pm 0.451$, and $0.429 \pm 0.515 \mathrm{mmol} \mathrm{Hg} / \mathrm{g}$ EPS, respectively (Table 2) and observed patterns only partially confirmed those of the atolls EPS. He 800 with a composition very similar to that of Mo 245 (Table 1) had an uptake very similar to that of the later as did HYD 1545, a more similar EPS to RA 19 and Mo 203. These three EPS, however, shared their composition with MS 907, which 
had the highest uptake capacity. Apparently, binding of $\mathrm{Hg}$ depends on other parameters of the EPS such as its native structure and the very different size of the polymers (Table 1) in addition to chemical composition.

Release of $\mathrm{Hg}$ from EPS-Hg complexes. Mo 245, the EPS with the highest $\mathrm{Hg}$ binding capacity (Figures 1, Figure S2, and Table 2), was selected to determine if $\mathrm{Hg}$ could be removed from the EPS-bound state by washing the EPS-Hg complex with solutions of various pH's. Two Hg concentrations were selected, $50 \mathrm{mg} / \mathrm{l}$ and $200 \mathrm{mg} / \mathrm{l}$ because they represented two unique points in the equilibrium isotherm (Figure 1), below and above the saturation level, respectively. The initial amount of $\mathrm{Hg}$ bound to Mo 245 was $7.99 \pm 1.23 \mu \mathrm{g} / \mathrm{mg}$ EPS (average and stdev of 9 replicate samples) after reacting with $50 \mathrm{mg} / \mathrm{l} \mathrm{Hg}$ and $9.25 \pm 2.12 \mu \mathrm{g} / \mathrm{mg}$ EPS after reacting with $200 \mathrm{mg} / \mathrm{l} \mathrm{Hg}$ (Table S1).

For both $\mathrm{Hg}$ concentrations tested, a similar pattern was observed (Figure 2; for values used to compute percent $\mathrm{Hg}$ removed by washing see Table S1) with a statistically significant difference in percent $\mathrm{Hg}$ removed by washing solutions with different $\mathrm{pH}$ values ( $\mathrm{p}$-value $\leq 0.0001$ ). The least amount of $\mathrm{Hg}$ was removed from the EPS by washing with pure water ( $\mathrm{pH} \sim 7$ ), 5 to $40 \%$ of the initially bound $\mathrm{Hg}$, regardless of initial $\mathrm{Hg}$ concentration. This treatment likely removed loosely bound $\mathrm{Hg}$. At under saturation some specific sites were still available to bind $\mathrm{Hg}$ and at oversaturation additional binding must have been due to weak associations and washing with water should remove this weakly-bound $\mathrm{Hg}$. That much less $\mathrm{Hg}$ was removed from $\mathrm{EPS}-\mathrm{Hg}$ complexes formed at under saturation (5.82\% of bound) as compared to oversaturation 
$(40.8 \%)$ confirm the presence of such weak interactions that lead to additional binding once more specific binding sites are saturated.

To examine binding by specific moieties in Mo 245, the Hg-EPS complex was washed with solutions of differing $\mathrm{pH}$, either acidic $(\mathrm{pH}=4)$ or basic $(\mathrm{pH}=9)$. Each functional group has a different acid dissociation constant, $\mathrm{pK}_{\mathrm{a}}$ and selecting a $\mathrm{pH}$ value above or below this value will increase and decrease the ionization state of the molecule, respectively, and determine whether or not $\mathrm{Hg}$ will be able to associate with it. If more $\mathrm{Hg}$ was released by a basic or acid solution, it would suggest alterations in the ionization of a particular functional group, depending on this group's $\mathrm{pK}_{\mathrm{a}}$, was the cause of the release. When the EPS was washed with the basic solution, 66 to $82 \%$ of the bound $\mathrm{Hg}$ was removed. Hexosamines have a $\mathrm{pK}_{\mathrm{a}}$ value between 7.87 and 8.49 , so at a $\mathrm{pH}$ of 9 the ionization state of the functional groups will have shifted toward the amino group (Sinnott 2007). This shift in ionization would alter the ability of the hexosamines to associate with $\mathrm{Hg}$ leading to the release of the bound $\mathrm{Hg}$. Therefore, the large amount of $\mathrm{Hg}$ that was removed by washing at $\mathrm{pH} 9$ (Figure 2) supports the hypothesis that hexosamines is a functional group that binds $\mathrm{Hg}$ in Mo 245.

The release of $\mathrm{Hg}$ from the EPS by washing with a solution at $\mathrm{pH} 4$ could implicate carboxyl groups, which account for $40 \%$ (W/W) of the Mo 245 (Table 1) and is traditionally thought of as the a functional group responsible for metal cation sorption (Volesky 1990). The $\mathrm{pK}_{\mathrm{a}}$ of carboxyl groups is 4.76 , so at $\mathrm{pH} 4$, the ionization state of this functional group would be altered affecting its ability to sorb $\mathrm{Hg}$. Indeed, washing the EPS at $\mathrm{pH} 4$ resulted in the release of $29 \%$ of total $\mathrm{Hg}$ from EPS-Hg formed at under saturation, to $49 \%$ from complexes formed at supersaturation. Thus, two 
functional groups in Mo 245 likely account for the high Hg sorption capacity of this EPS, the amino groups of hexosamines and the carboxyl groups of uronic acids.

Effects of EPS on $\mathrm{Hg}$ tolerance. The binding of $\mathrm{Hg}$ to EPS raises the possibility that EPS may protect the producing bacteria from the toxicity of $\mathrm{Hg}$ as has been suggested for other metals (Teitzel and Parsek 2003). Because EPS varied in their ability to bind $\mathrm{Hg}$ (Figures 1, Figure S2, Table 2) and in their relative content of uronic acid, a major component of colanic acid (Guézennec et al. 2011), and hexosamines (Table 1), we examined how mutations that impair EPS production affected $\mathrm{Hg}$ resistance in E. coli K12 strains. We first performed a standard nucleotide BLAST search of the National Center for Biotechnology Information (NCBI) nucleotide database (http://blast.ncbi.nlm.nih.gov/Blast.cgi?PROGRAM=blastn\&PAGE_TYPE=BlastSearch\& LINK_LOC=blasthome) to determine that $E$. coli $\mathrm{K}-12$ does not contain a merA homolog, which could be a confounding factor.

In order to compare the $\mathrm{Hg}$ tolerance of different $E$. coli strains, the disc inhibition test was performed. Varying amounts, ranging from 100 to 1,000 nmole, of $\mathrm{Hg}$ were impregnated onto a sterile filter paper discs that were placed on a solid medium plate inoculated with a lawn of bacteria. The Hg diffuses into the medium from the filter paper creating a gradient of concentration highest close to the filter paper disc and decreasing with distance from the disc. Bacterial growth is only possible up to the region where the concentration of $\mathrm{Hg}$ is tolerable (Figure $3 \mathrm{a}$ ) and, on a comparative basis, a larger zone of inhibition indicates more sensitivity to $\mathrm{Hg}$ (Barkay et al. 1990). There was no inhibition of growth for any of the strains tested when sterile ultra pure water was placed on the disc as indicated by zones of inhibition equal to zero millimeters $(\mathrm{mm})$ (data not shown). 
The first test system consisted of strain ZK2686 (W3110 $\Delta[\arg F$-lac]U169) and its wcaF mutant strain ZK2687 (ZK2686 wcaF31::cam). The wcaF gene belongs to a cluster of genes responsible for the production of colanic acid and it encodes for a NodL-like protein that is closely related to a large family of acetyltransferases and that in Rhizobium O-acetylates Nod factors. Therefore, it is believed that WcaF is involved in the $O$-acetylation of colanic acid. Because there is a second putative $O$-acetylase gene present in the colonic acid gene cluster (Stevenson et al. 1996), strain ZK2687 is a defective, rather than a null mutant for colanic acid production, and is able to produce a biofilm with a deformed architecture after prolonged incubation (Danese et al. 2000).

For strains ZK2686 (wild-type) and strain ZK2687 (mutant) zones of inhibition increased in a dose-dependent manner (Figure 3b). Zones of inhibition for the wild type strain ranged from $1.4 \mathrm{~mm}$ to $6.1 \mathrm{~mm}$. For the mutant strain, the zones of inhibition were larger and ranged from $2.5 \mathrm{~mm}$ to $7.15 \mathrm{~mm}$ with more variability in the increase in zone with increasing $\mathrm{Hg}$ mass. Increase in size of zone of inhibition with increasing $\mathrm{Hg}$ mass was statistically significant at a $p-\leq 0.05$. At each mass tested, the mutant strain had a zone of inhibition $1 \pm 0.1 \mathrm{~mm}$ larger than the wild-type and this difference was statistically significant $(p \leq 0.05)$. To examine if this difference of resistance was related to EPS production we measured EPS production and normalized it to protein content of the producing biomass (Tay et al. 2001; Vandevivere and Kirchman 1993). The wild-type strain produced more than twice as much EPS than the mutant with $6.4 \pm 1.3 \mu \mathrm{g} \mathrm{EPS} / \mathrm{mg}$ protein compared to $2.7 \pm 0.7 \mu \mathrm{g} / \mathrm{mg}$, respectively, and this difference was highly significant $(p \leq 0.05)$. Since the major difference between the two strains is EPS production, i.e., colanic acid, production (Danese et al. 2000), we conclude that EPS 
provide a low level of protection against $\mathrm{Hg}$ toxicity to $E$. coli $\mathrm{K}-12$ strains possibly due to binding of $\mathrm{Hg}$ to the EPS matrix (Figures 1, Table 2).

The second test system that we employed allowed us to distinguish the roles of colanic acid and hexosamine-containing EPS in Hg tolerance. The wild type strain, MG1655 ( $\left.\mathrm{F}^{-} \lambda^{-}\right)$has normal production of both colanic acid and hexosamine. TRMG1655 (MG1655 csrA::kan) has a transposon insertion in the csrA gene whose product, CsrA, represses biofilm formation by global regulation of central carbon flux. Therefore, biofilm formation is enhanced in TRMG1655 compared to strain MG1655 (Wang et al. 2004). Strains DJ4 and TRXWMG $\Delta C$ are derivatives of TRMG1655, the first has a knockout mutation in the cpsE gene which specifies colanic acid biosynthesis but intact production of hexosamines. Strain TRXWMG $\Delta \mathrm{C}$ (TRMG1655 $\Delta$ pgaC; hexosamine minus) has a deletion of $p g a C$, a gene specifying polysaccharide polymerase using UDP-GIcNAc as a substrate, decreasing hexosamine production; the strain is capable of producing colanic acid (Wang et al. 2004).

For strain MG1655 and its derivatives, $\mathrm{Hg}$ inhibited growth in a dose dependent manner (Figure 3c). Zones of inhibition ranged as follows: parent strain, $7.0 \mathrm{~mm}$ to 12.4 $\mathrm{mm}$; enhanced biofilm producer, $5.6 \mathrm{~mm}$ to $11.8 \mathrm{~mm}$; hexosamine minus mutant, 7.3 $\mathrm{mm}$ to $13.4 \mathrm{~mm}$; and colanic acid minus mutant, $7.6 \mathrm{~mm}$ to $13.1 \mathrm{~mm}$. The $c s r A$ mutant (strain TRMG1655) was as resistant to $\mathrm{Hg}$ as the wild type (strain MG1655) at all levels of $\mathrm{Hg}$ additions with the exception of the lowest $\mathrm{Hg}$ mass tested, 100 nanomoles, where the former had the smallest zone of inhibition of $5.6 \mathrm{~mm}$ compared to the other strains whose zone of inhibition at this mass were between 7.0 and $7.6 \mathrm{~mm}$. Together, the results show a difference of about $1 \mathrm{~mm}$ in the zone of inhibition between strains that 
produced both colonic acid and hexosamine EPS, similar to observations with strains ZK2686 and ZK2687 (Figure 3b). The results suggest that (i) loss of the ability to produce either EPS increases sensitivity to $\mathrm{Hg}$, (ii) there was no difference in $\mathrm{Hg}$ sensitivity between colonic acid and glucosamine-based EPS, and (iii) increased production of biofilm in the csrA mutant (Wang et al. 2004) did not increase $\mathrm{Hg}$ tolerance except at very low level of exposure. We note, though, that growth on solid medium, used in the disc inhibition test, might have masked differences between strains varying in biofilm production. EPS production by strain MG1655 and its three mutant derivatives was not tested.

\section{Discussion}

This research reports binding of $\mathrm{Hg}$ (II) to EPS that are produced by marine bacteria, and that this binding is enhanced in EPS that contain hexosamine and/or uronic acid moieties relative to those that consist solely of neutral sugars. We also show that one biological consequence of producing EPS is an increased tolerance of the producing bacteria to $\mathrm{Hg}(\mathrm{II})$. These findings are significant in light of (i) the use of biopolymers as $\mathrm{Hg}$ chelators in medicine (Zanchetta et al. 2003) and environmental remediation (Edwards and Kjellerup 2013), and (ii) paradigms of $\mathrm{Hg}$ tolerance mechanisms in bacteria (Barkay and Wagner-Döbler 2005).

Previous studies examined binding of different metals by some of the EPS that were used here, allowing for a comparison of their efficiencies as chelators of different metals. Moppert et al. (2009) followed the protocol used here to study metal binding by RA 19, an EPS that contains only neutral sugars and sulfate with low levels of uronic 
acid (Table 1). They report cupric copper uptake capacities of $9.84 \mathrm{mmol} / \mathrm{g}$ and those for ferrous iron of $6.9 \mathrm{mmol} / \mathrm{g}$, were 40 times and 28 times higher, respectively than the $\mathrm{Hg}$ (II) uptake capacity. As for RA 19, the uptake capacities for HE 800 were greater for other metals compared to $\mathrm{Hg}(\mathrm{II})$. However, the difference between capacities was smaller with values ranging from 2.3 to 2.7 times higher for cadmium, silver, and zinc compared to $\mathrm{Hg}$ (II) (Loaëc et al. 1998). It has been found that these metal cations can out-compete $\mathrm{Hg}$ (II) for binding to various biopolymers suggesting a higher affinity to the EPS. Other EPS, depending on their composition, may preferentially bind $\mathrm{Hg}$ and amino groups may be key to this binding. (Indeed, Mo 245 and He800, the only hexoseamine containing EPS that were tested here (Table 1), had high Hg(II) Qmax (Table 2).)

Polyaminated chitosan (deacetylated polymer of chitin) has been demonstrated to be highly selective for $\mathrm{Hg}(\mathrm{II})$, out-competing other metals for binding sites. The amine groups in chitosan can adsorb metals through several mechanisms such as chelation, ion exchange or the formation of ion pairs (Barriada et al. 2008; Jeon and Hall 2003; Jeon and Park 2005; Kawamaura et al. 1993; Masri et al. 1972). Son et al. (2004) reported a very high uptake up to $9.45 \mathrm{mmole}$ of $\mathrm{Hg}(\mathrm{II}) / \mathrm{g}$ EPS for chitosan and others indicated $\mathrm{Hg}$ binding capacity by chitosan ranging from $1.8 \mathrm{mmole} / \mathrm{g}$ EPS to $2.3 \mathrm{mmole}$ /g EPS, depending upon the origin of the polymer (Cárdenas et al. 2001; Miretzky and Cirelli 2009; Rio and Delebarre 2003). Therefore, comparing Hg(II) binding of deacetylated HE800 and Mo 245 to that of the unadultered EPS might test our hypothesis on the role of hexosamines in $\mathrm{Hg}$ (II) binding. If correct, we would expect an increase in $\mathrm{Hg}$ sequestration upon deacetylation. The size of the metal ion may also 
affect preferential binding; an EPS produced by the psychrophilic bacterium Pseudomonas fluorescens BM07 preferentially bound larger ions such as $\mathrm{Hg}(\mathrm{II})$ over smaller ones. This high sorption was explained as partially due to a predominant van der Waals interaction between the cation and the biopolymer (Noghabi et al. 2007). As a soft ion, $\mathrm{Hg}(\mathrm{II})$ forms strong bonds with groups containing nitrogen and sulfur atoms (Pearson 2005).

PRIOR RESULTS WITH OTHER METALS (Loaëc et al. 1998; MOPPERT ET AL. 2009) AND OUR CURRENT FINDINGS ON THE INTERACTION OF VARIOUS EPS WITH HG(II) SHED LIGHT ON THE METAL-BINDING CAPACITIES OF VARIOUS MOIETIES IN EPS. AMONG THE EPS WE TESTED, Mo 245, an eps dominated by hexosamine and uronic acids (table 1), was the most efficient WHILE gg, the least efficient in binding hg is exclusively made of NEUTRAL sugars. APPARENTLY, NEUTRAL SUGAR-RICH EPS BIND LESS HG(II) THAN THOSE POSSESSING URONIC AND HEXOSE AMINE GROUPS AS HAS BEEN REPORTED FOR OTHER HEAVY METAL CATIONS (SON ET AL. 2004). THUS, OUR RESULTS point to the importance of uronic acids and hexosamine as hg binding moieties. this conclusion was strongly supported by washing experiments (figURE 2) OF HG-MO 245 COMPLEXES SHOWING SIGNIFICANT REMOVAL OF BOUND HG WHEN THE PH OF THE SOLUTION AFFECTED THE PKA OF HEXOSAMINE (PH 9) OR uronic acid (pH 4). As is the case for metal binding by biomass (Ramrakhiani et al. 2016), the nature of available ligands in EPS on metal binding capacities is expected. In general, heavy metals biosorption can be explained by considering different kinds of physical and chemical interactions among metals in solution and the different functional groups present in many EPS such as 
carboxylic, sulfate, hydroxyl and amino groups along with the presence of noncarbohydrate residues. It has been also postulated that the higher the electrophelicity of a metal, the higher is its affinity towards negatively charged EPS (Singh et al. 2000; Tangkawanit et al. 2005; Uudesmaa and Tamm 2004). While uronic acids-rich EPS sorb $\mathrm{Hg}(\mathrm{II})$ efficiently, a comparison among the different EPS shows that the metal uptake capacity is not directly proportional to the uronic acids content (Tables 1 and 2). This functional group is therefore an important, but not the sole factor, determining the metal binding capacity of EPS.

Sorption of metal to biological material is routinely used in the management of contamination waste streams, ecosystems, and in human health. Most intriguingly, the high capacity of some of the EPS tested here to bind $\mathrm{Hg}$ (II), e.g., Mo 245 and HE800, could potentially be used in medicine. EPS may serve as chelators in patients with acute $\mathrm{Hg}$ poisoning. Currently activated charcoal is administered in for this purpose; however, its efficiency as a treatment is debated. Other treatment options include chelators such as penicilliamine, dimercapol, and unithiol; but these have strong side effects including nephrotoxicity, hypersensitivity, Gl disorders, convulsions, and headache (Rafati-Rahimzadeh et al. 2014). The clinical use of bacterial EPS has gained attention in recent years (Nichols et al. 2005; Senni et al. 2013; Zanchetta et al. 2003), and they might be a safer way to effectively chelate $\mathrm{Hg}$ in the human body. Another potential use for these EPS is the bioremediation of $\mathrm{Hg}$ contaminated waste streams. The application of EPS for the bioremediation of heavy metal contaminated sites has received considerable interest in the past couple of decades as an eco-friendly and cost 
effective method for metal removal (François et al. 2012; Kazy et al. 2002; Kiliç and Dönmez 2008; Loaëc et al. 1998; Moppert et al. 2009).

The observation of $\mathrm{Hg}(\mathrm{II})$ binding to EPS raises the question of what role does this phenomenon play in the ecology of microbes that live in contaminated environments. EPS were long considered to enhance bacterial tolerance to toxic metals. This is most clearly evident by the relative metal resistance of biofilms as compared to planktonic cells (e.g. Teitzel and Parsek 2003) a conclusion supported by studies showing that cellular metal binding is directly related to EPS production and to the EPS content of acidic moieties (François et al. 2012; Kazy et al. 2002). However, metal tolerance in biofilms may be enhanced not only by binding to EPS but also by the protection of deeper biofilm layers when affected outer layers die and sequester the metals or by the presence within the biofilm of stationary phase cells with their innate lower susceptibility (Teitzel and Parsek 2003). For this reason, studies that employ EPS producing bacteria and their EPS impaired mutants are needed to determine how sequestration protects microbes from metal toxicity.

Here we compared the $\mathrm{Hg}$ resistance levels of E. coli K-12 strains with their EPSimpaired mutants, focusing on mutations that altered levels of colanic acid and hexosamine. Results suggested that EPS production may provide a low level of tolerance the $\mathrm{Hg}$ (Figures 3) and pointed out to the importance of both carboxyl groups in colanic acid and amino groups in hexosamines as possible binding sites for $\mathrm{Hg}$ (II). We are only aware of one previous study that examined EPS binding of $\mathrm{Hg}$ as the basis for $\mathrm{Hg}$ tolerance and while the authors clearly showed $\mathrm{Hg}$ binding to biomass and to biomass-produced EPS (François et al. 2012), clear evidence for the role of binding in 
increasing $\mathrm{Hg}$ tolerance was not presented. We believe that to connect resistance to EPS production one needs to show that strains that do not produce EPS are more sensitive than producing strains.

The current paradigm for microbial $\mathrm{Hg}$ resistance invokes reduction to the volatile elemental form, $\mathrm{Hg}(0)$ (Barkay et al. 2003; Marteyn et al. 2013). mer systems provide resistance to $\mu \mathrm{M}$ to $\mathrm{mM}$ concentrations of $\mathrm{Hg}$ and resistant strains may be orders of magnitude more resistant than their mer-less isogenic strains (Barkay et al. 2003). In comparison, the EPS-dependent resistance reported here endows only a low level of Hg tolerance. Consistent with our observations, Hidalgo et al. (2010) used curli producing E. coli strains and their non-producing mutants to show that $\mathrm{Hg}$ sequestration by curli, proteinaceous fimbriae present on the surface of many Enterobacteriaceae, which function in cell adhesion, aggregation, and biofilm formation (Barnhart and Chapman 2006), modestly but significantly increased $\mathrm{Hg}$ (II) tolerance (Hidalgo et al. 2010). Thus, it is possible that in addition to the robust and energetically costly mermediated resistance, extracellular sequestration of $\mathrm{Hg}$ provides a modest defense against $\mathrm{Hg}$ toxicity. This modest level of tolerance may be sufficient to increase the fitness of microbes in environments where a low level of protection by the EPS could enhance the competitiveness of producing strains. Biofilms with their high EPS content (Flemming and Wingender 2010) and high Hg sorption capacity (Cheng et al. 2008; Hintelmann et al. 1993) may be such environment.

In summary, our results point to a role of EPS in $\mathrm{Hg}$ (II) binding and bacterial tolerance and suggest that hexosamines and carboxyl groups in marine EPS bind 
$\mathrm{Hg}(\mathrm{II})$. These results imply that polymers rich in such moieties may have potential applications in human health and environmental remediation.

\section{Acknowledgments}

The authors acknowledge Pacific Biotech SAS (Dr. Xavier Moppert) (Tahiti, French Polynesia) for providing us with EPS from microbial mats from French Polynesian atolls. We also acknowledge the laboratories of Dr. Roberto Kolter, Harvard Medical School, and Dr. Tony Romeo, University of Florida, for providing us with the $E$. coli strains. Shelly Carpenter and Dr. Jody Deming, University of Washington, are appreciated for providing protocols and advice on EPS measurements. We thank Drs. Kenneth Reuhl, Brian Buckley, Keith Cooper, and Costantino Vetriani for their constructive suggestions. This research was supported by the National Institutes of Health (NIH) grant R25GM-58389, the Environmental and Occupational Health Sciences Institute ES005022, Education and Extension Services, the National Institute of Environmental Health Sciences ES00178.

\section{Compliance with ethical standards}

This article does not contain any studies with human participants or animals performed by any of the authors.

\section{Conflict of interest}

The authors declare that they have no conflict of interest 


\section{References}

ATSDR, US (1999) Toxicological profile for mercury (Update). Atlanta, GA: US Agency for Toxic Substances and Disease Registry.

Barkay T, Gillman M, Liebert C (1990) Genes encoding mercuric reductases from selected gram-negative aquatic bacteria have a low degree of homology with merA of transposon Tn501. Appl Environ Microbiol 56:1695-1701

Barkay T, Miller SM, Summers AO (2003) Bacterial mercury resistance from atoms to ecosystems. FEMS Microbiol Rev 27:355-384. doi: 10.1016/S01686445(03)00046-9

Barkay T, Wagner-Döbler I (2005) Microbial transformations of mercury: potentials, challenges, and achievements in controlling mercury toxicity in the environment. Adv Appl Microbiol 57:1-52. doi: 10.1016/S0065-2164(05)57001-1

Barnhart MM, Chapman MR (2006) Curli biogenesis and function. Annu Rev Microbiol 60:131-147. doi:10.1146/annurev.micro.60.080805.142106

Barriada JL, Herrero R, Prada-Rodríguez D, Sastre de Vicente MR (2008) Interaction of mercury with chitin: a physicochemical study of metal binding by a natural polymer. React Funct Polym 69:1609-1618. doi:

10.1016/j.reactfunctpolym.2008.09.002

Beveridge TJ, Koval SF (1981) Binding of metals to cell envelopes of Escherichia coli K-12. Appl Environ Microbiol 42:325-335 
Bozzi L, Milas M, Rinaudo M (1996) Characterization and solution properties of a new exopolysaccharide excreted by the bacterium Altermonas sp. strain 1644. Int $J$ Biol Marcomol 18:9-17. doi:10.1016/0141-8130(95)01038-6

Cárdenas G, Orlando P, Edelio T (2001) Synthesis and applications of chitosan mercaptanes as heavy metal retention agent. Int J Biol Marcomol 28:167-174. doi: 10.1016/S0141-8130(00)00156-2

Cheng JP, Zhao WC, Liu YY, Wu C, Liu C, Wang WH (2008) Adsorption properties and gaseous mercury transformation rate of natural biofilm. Bull Environ Contam Toxicol 81:516-520. doi: 10.1007/s00128-008-9526-2

Clarkson TW (1998) Human toxicology of mercury. J Trace Elem Exp Med 11:303317. doi: 10.1002/(SICI)1520-670X(1998)11:2/3<303::AID-JTRA18>3.0.CO;2-V

Clarkson TW, Magos L (2006) The toxicology of mercury and its chemical compounds. Crit Rev Toxicol 36:609-662. doi:10.1080/10408440600845619

Dada AO, Olalekan AP, Olatunya AM, Dada O. (2012) Langmuir, Freundlich, Temkin, and Dubinin-Radushkevich isotherms studies of equilibrium sorption of $\mathrm{Zn}^{2+}$ unto phosphoric acid modified rice husk. IOSR J Appl Chem 3:38-45. doi: 10.9790/5736-0313845

Danese PN, Pratt LA, Kolter R (2000) Exopolysaccharide production is required for development of Escherichia coli K-12 biofilm architecture. J Bacteriol 182:35933596. doi: 10.1128/JB.182.12.3593-3596.2000

de la Rosa G, Reynel-Avila HE, Bonilla-Petriciolet A, Cano-Rodriguez I, VelascoSantos C, Martínez-Hernández AL (2008) Recycling poultry feathers for Pb removal from wasterwater: kinetic and equilibrium studies. Proc World Acad Sci Eng Technol 30:1011-1019 
DuBois M, Gilles KA, Hamilton JK, Rebers PA, Smith F (1956) Colorimetric method for determination of sugars and related substances. Anal Chem 28:250-256. doi: 10.1021/ac60111a017

Dueñas-Chasco MT, Irastorza-Iribas A, Rodríguez-Carvajal MA, Tejero-Mateo P, Gil-Serrano AM, Espartero JL (1998) Structural analysis of the exopolysaccharides produced by Lactobacillus spp. G-77. Carbohydr Res 307:125-133. doi:

10.1016/S0008-6215(98)00034-2

Edwards SJ and Kjellerup BV (2013) Applications of biofilms in bioremediation and biotransformation of persistent organic pollutants, pharmaceuticals/personal care products, and heavy metals. Appl Microbiol Biotechnol 97:9909-9921. doi: 10.1007/s00253-013-5216-z

Evans JR, Davids WG, MacRae JD, Amirbahman A (2002) Kinetics of cadmium uptake by chitosan-based crab shells. Water Res 36:3219-3226. doi:

10.1016/S0043-1354(02)00044-1

François F, Lombard C, Brian-Jaisson F, Martino G, Vandervennet M, Peduzzi J, Zirah S, Rebuffat S, Guigner JM, Soreau P, Garcia D, Molinier AL, Pignol D (2012) Isolation and characterization of environmental bacteria capable of extracellular biosorption of mercury. Appl Environ Microbiol 78:1097-1106. doi:

10.1128/AEM.06522-11

Freire-Nordi CS, Vieira AAH, Nascimento OR (2005) The metal binding capacity of Anabaena spiroides extracellular polysaccharide: an EPR study. Process Biochem 40:2215-2224. doi:10.1016/j.procbio.2004.09.003

Flemming HC, Wingender J (2010) The biofilm matrix. Nature Rev Microbiol 8:623633. doi:10.1038/nrmicro2415 
Guézennec J, Moppert X, Raguénès G, Richert L, Costa B, Simon-Colin C (2011) Microbial mats in French Polynesia and their biotechnological applications. Process Biochem 46:16-22. doi:10.1016/j.procbio.2010.09.001

Guibaud G, van Hullebusch E, Bordas F (2006) Lead and cadmium biosorption by extracellular polymeric substances (EPS) extracted from activated sludges: $\mathrm{pH}$ sorption edge tests and mathematical equilibrium modelling. Chemosphere 64:19551962. doi: 10.1016/j.chemosphere.2006.01.012

Hidalgo G, Chen X, Hay AG, Lion LW (2010) Curli produced by Escherichia coli PHL628 provide protection from Hg(II). Appl Environ Microbiol 76:6939-6941. doi: 10.1128/AEM.01254-10

Hintelmann H, Ebinghaus R, Wilken RD (1993) Accumulation of mercury(II) and methylmercury by microbial biofilms. Water Res 27:237-242. doi: 10.1016/00431354(93)90081-R

Jeon C, Höll WH (2003) Chemical modification of chitosan and equilibrium study for mercury ion removal. Water Res 37:4770-4780. doi: 10.1016/S0043-1354(03)004317

Jeon C, Park KH (2005) Adsorption and desorption of mercury (II) using aminated chitosan beads. Water Res 39:3938-3944. doi:10.1016/j.watres.2005.07.020

Kawamaura Y, Mitsuhashi M, Tanibe H, Yoshida H (1993) Adsorption of metal ions on polyaminated highly porous chitosan chelating resin. Ind Eng Chem Res 32:386391. doi:10.1021/ie00014a015

Kazy SK, Sar P, Singh SP, Sen AK, D'Souza SF (2002) Extracellular polysaccharides of a copper-sensitive and a copper-resistant Pseudomonas 
aeruginosa strain: synthesis, chemical nature, and copper binding. World J Microbiol Biotechnol 18:583- 588. doi:10.1023/A:1016354713289

Kiliç NK, Dönmez G (2008) Environmental conditions affecting exopolysaccharide production by Pseudomonas aeruginosa, Micrococcus sp., and Ochrobactrum sp. J Hazard Mater 154:1019- 1024. doi: 10.1016/j.jhazmat.2007.11.008

Lin CC, Yee N, Barkay T (2012) Microbial transformations in the mercury cycle. In: Liu G, Cai Y, O'Driscoll N (ed) Advances in Environmental Chemistry and Toxicology of Mercury. Wiley, New Jersey, pp 155- 180.

Loaëc M, Olier R, and Jean Guézennec (1997) Uptake of lead, cadmium and zinc by a novel bacterial exopolysaccharide. Water Res 31:1171- 1179 doi:10.1016/S00431354(96)00375-2

Loaëc M, Olier R, and Jean Guézennec (1998) Chelating properties of bacterial exopolysaccharides from deep-sea hydrothermal vents. Carbohydr Polym 35:65-70. doi:10.1016/S0144-8617(97)00109-4

Macaskie LE, Dean ACR (1990) Metal-sequestering biochemicals. In: Volesky (ed) Biosorption of heavy metals. CRC Press, Florida, pp 199-248

Mann H (1990) Biosorption of heavy metals by bacteria biomass. In: Volesky (ed) Biosorption of heavy metals. CRC Press, Florida, pp 93-139

Marteyn B, Sakr S, Farci S, Bedhomme M, Chardonnet S, Decottignies P, Lemarie S, Cassier-Chauvat C, and Chauvat F (2013) The Synechocystis PCC6803 MerAlike enzyme operates in the reduction of both mercury and uranium under the control of the glutaredoxin 1 enzyme. J Bacteriol 195(18):4138-4145. doi:10.1128/JB.0027213 
Masri MS, Mendel F (1972) Mercury uptake by polyamine- carbohydrates. Environ Sci Technology 6:745-746. doi:10.1021/es60067a010

Miretzky P, Cirelli AF (2009) $\mathrm{Hg}$ (II) removal from water by chitosan beads and chitosan derivatives: A review. J Hazard Mater 167:10-23. doi:10.1016/j.jhazmat.2009.01.060

Moppert X, Le Costaouec, Raguénès G, Courtois A, Simon-Colin C, Crassous $P$, Costa B, Guezénnec J (2009) Investigations into the uptake of copper, iron, and selenium by a highly sulphated bacterial exopolysaccharide isolated from microbial mats. J Ind Microbiol Biotechnol 36:599-604. doi:10.1007/s10295-009-0529-8

Nichols CAM, Guézennec J, Bowman JP (2005) Bacterial exopolysaccharides from extreme marine environments with special considerations of the Southern Ocean, sea ice, and deep-sea hydrothermal vents: A review. Marine Biotechnol 7:253-271. doi: 10.1007/s10126-004-5118-2

Noghabi KA, Zahiri HS, Yoon SC (2007) The production of a cold-induced extracellular biopolymer by Pseudomonas fluorescens BM07 under various growth conditions and its role in heavy metals absorption. Process Biochem 42:847-855. doi:10.1016/j.procbio.2007.02.004

Onsanit S, Wang WX (2011) Sequestration of total and methyl mercury in different subcellular pools in marine caged fish. J Hazard Mater 198:113-122. doi: 10.1016/j.jhazmat.2011.10.020

Paperi R, Micheletti E, De Philippis R (2006) Optimization of copper sorbingdesorbing cycles with confined cultures of the exopolysaccharide- producing cyanobacterium Cyanospira capsulata. J Appl Microbiol 101:1351-1356. doi: 10.1111/j.1365-2672.2006.03021.x 
Pearson RG (2005) Chemical hardness and density functional theory. J Chem Sci 117:369-377. doi: 10.1007/BF02708340

Pulsawat W, Leksawasdi N, Rogers PL, Foster LJR (2003) Anion effects on biosorption of Mn (II) by extracellular polymeric substance (EPS) from Rhizobium etli. Biotechnol Lett 25:1267-1270. doi: 10.1023/A:1025083116343

Rafati-Rahimzadeh M, Rafati-Rahimzadeh M, Kazemi S, Moghadamnia AA (2014) Current approaches of management of mercury poisoning: need of the hour. DARU J Pharm Sci 22:1-10. doi:10.1186/2008-2231-22-46

Raguénès G, Cambon-Bonavita MA, Lohier JF, Boisset C, and Guézennec J (2003) A novel, highly viscous polysaccharide excreted by an Alteromonas isolated from a deep-sea hydrothermal vent shrimp. Curr Microbiol 46:448-452. doi:10.1007/s00284-002-3922-3

Ramrakhiani L, Ghosh S, Majumdar S (2016) Surface modification of naturally available biomass for enhancement of heavy metal removal efficiency, upscaling prospects, and management aspects of spent biosorbent: A review. Appl Biochem Biotecnol 180:41-78. doi:10.1007/s12010-016-2083-y Rio S, Delebarre A (2003) Removal of mercury in aqueous solution by fluidized bed plant fly ash. Fuel 82:153-159. doi: 10.1016/s0016-2361(02)00237-5

Rougeaux H, Kervarec N, Pichon R, Guézennec J (1999) Structure of the exopolysaccharide of Vibrio diabolicus isolated from a deep-sea hydrothermal vent. Carbohydr Res 322:40-45. doi:10.1016/S0008-6215(99)00214-1

Senni K, Gueniche F, Changotade S, Septier D, Sinquin C, Ratiskol J, Lutomski D, Godeau G, Guézennec J, Colliec-Jouaut S (2013) Unusual glycosaminoglycans from a deep sea hydrothermal bacterium improve fibrillar collagen structuring and fibroblast activities in engineered connective tissues. Mar Drug 11:1351-1369. doi:10.3390/md11041351 
Singh S, Pradlan S, Rai LC (2000 ) Metal removal from single and multimetallic systems by different biosorbent materials as evaluated by differential pulse anodic stripping voltammetry. Process Biochem 36:175-182. doi: 10.1016/S00329592(00)00211-9

Sinnott, M (2007) Carbohydrate chemistry and biochemistry: Structure and mechanism, vol 18. RSC Publishing, Cambridge

Son BC, Park K, Hoon Song SH, Yoo YJ (2004) Selective biosorption of mixed heavy metal ions by using polysaccharides. Korean J Chem Eng 2:1168-1172. doi: 10.1007/BF02719489

Stevenson G, Andrianopoulos K, Hobbs M, Reeves PR (1996) Organization of Escherichia coli K-12 gene cluster responsible for production of the extracellular polysaccharide colanic acid. J Bacteriol 178:4885- 4893.

doi:10.1128/jb.178.16.4885-4893.1996

Sutherland IW (1990) Biotechnology of microbial exopolysaccharides, vol 9. Cambridge University Press, New York

Tay JH, Liu QS, Liu Y (2001) The role of cellular polysaccharides in the formation and stability of aerobic granules. Lett Appl Microbiol 33:222-226. doi:

10.1046/j.1472-765X.2001.00986.x

Tangkawanit S, Rangsriwatananon K, Dyer A (2005) lon exchange of $\mathrm{Cu}^{2+}, \mathrm{Ni}^{2+}$, $\mathrm{Pb}^{2+}$ and $\mathrm{Zn}^{2+}$ in analcime (ANA) synthesized from Thai perlite. Microporous Mesoporous Mater 79:171-175. doi:10.1016/j.micromeso.2004.10.040 
Teitzel GM, Parsek MR (2003) Heavy metal resistance of biofilm and planktonic Pseudomonas aeruginosa. Appl Environ Microbiol 69:2313-2320. doi:10.1128/AEM.69.4.2313-2320.2003

Uudsemaa M, Tamm T (2004) Calculation of hydration enthalpies of aqueous transition metal cations using two coordination shells and central ion substitution. Chem Phys Lett 400:54-58. doi: 10.1016/j.cplett.2004.10.082

Vandevivere P, Kirchman DL (1993) Attachment stimulates exopolysaccharide synthesis by a bacterium. Appl Environ Microbiol 59:3280-3286.

Vincent P, Pignet P, Talmont F, Bozzi L, Fournet B, Guézennec J, Jeanthon C, Prieur D (1994) Production and characterization of an exopolysaccharide excreted by a deep-sea hydrothermal vent bacterium isolated from the polychaete annelid Alvinella pompejana. Appl Environ Microbiol 60:4134-4141.

Volesky B (1990) Removal and recovery of heavy metals by biosorption. In: Volesky B (ed) Biosorption of heavy metals. CRC Press, Florida, pp 7-43

Wan Ngah WS, Ab Ghani S, Kamari A (2005) Adsorption behaviour of $\mathrm{Fe}(\mathrm{II})$ and $\mathrm{Fe}(\mathrm{III})$ ions in aqueous solution on chitosan and cross-linked chitosan beads. Bioresour Technol 96:443-450. doi:10.1016/j.biortech.2004.05.022

Wang X, Preston JF, Romeo T (2004) The pgaABCD locus of Escherichia coli promotes the synthesis of a polysaccharide adhesin required for biofilm formation. $J$ Bacteriol 186:2724-2734. doi:10.1128/JB.186.9.2724-2734.2004

Wiatrowski HA, Ward PM, Barkay T (2006) Novel reduction of mercury (II) by mercury-sensitive dissimilatory metal reducing bacteria. Environ Sci Technol 40:6690- 6696. doi:10.1021/es061046g 
Zanchetta P, Lagarde N, Guezennec J (2003) A new bone-healing material: A hyaluronic acid-like bacterial exopolysaccharide. Calcif Tissue Int 72:74-79. doi:10.1007/s00223-001-2091-x 


\section{Figures}

Fig. 1 Equilibrium sorption isotherms for $\mathrm{Hg}$ by EPS produced by microbial mats from French Polynesians atolls. $[\mathrm{Hg}]_{\text {eq }}$ is the measured concentration at equilibrium prior to filtration. Triplicates for each concentration are individually represented by similar marker shapes

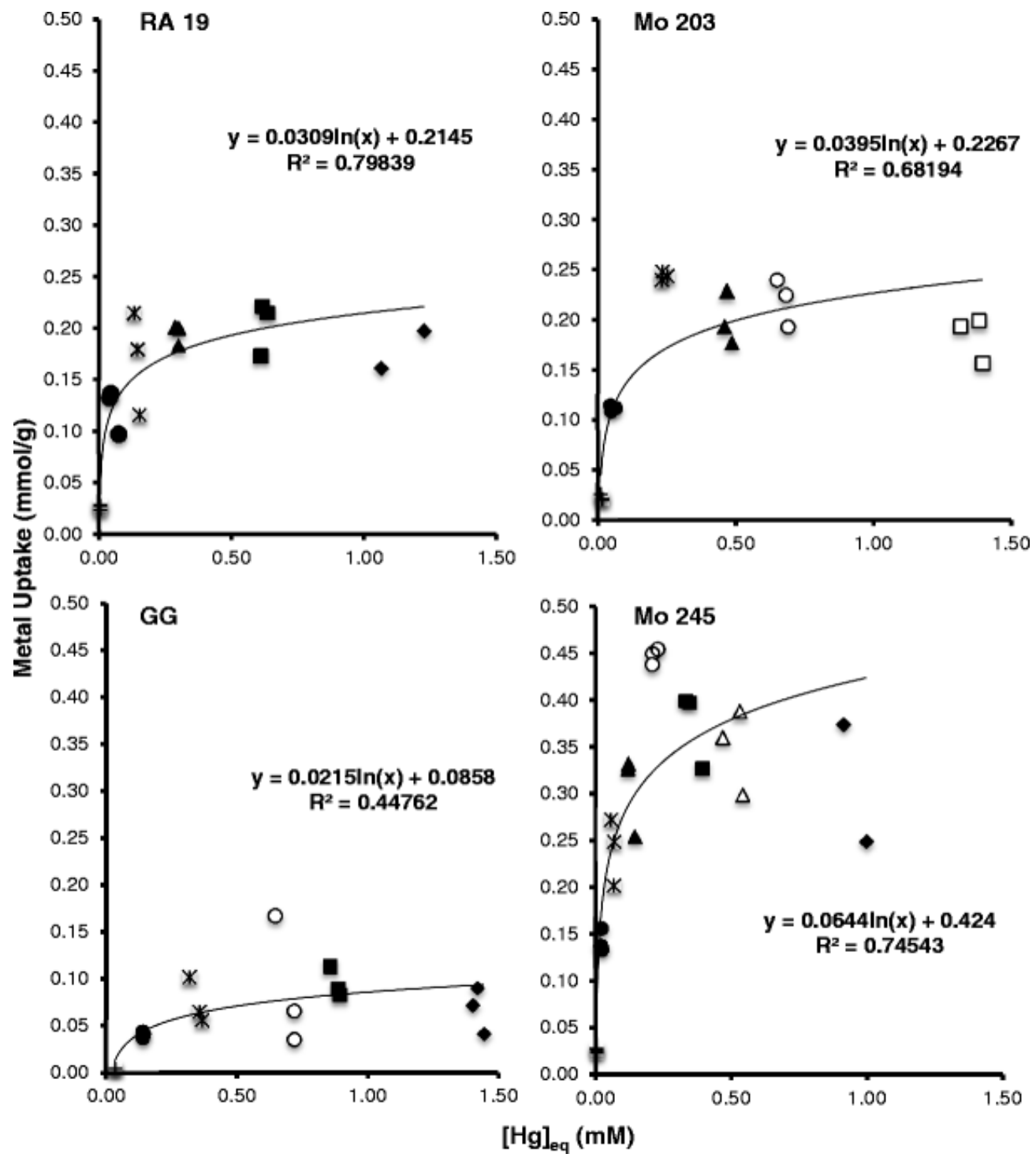


Fig. 2 Percent of $\mathrm{Hg}$ mass removed from the bound state to Mo 245 by washing solutions of various $\mathrm{pH}$ values. Initial $\mathrm{Hg}$ concentrations of $50 \mathrm{mg} / \mathrm{l}$ (black bars) and 200 $\mathrm{mg} / \mathrm{l}$ (grey bars) were used to sorb Hg to EPS

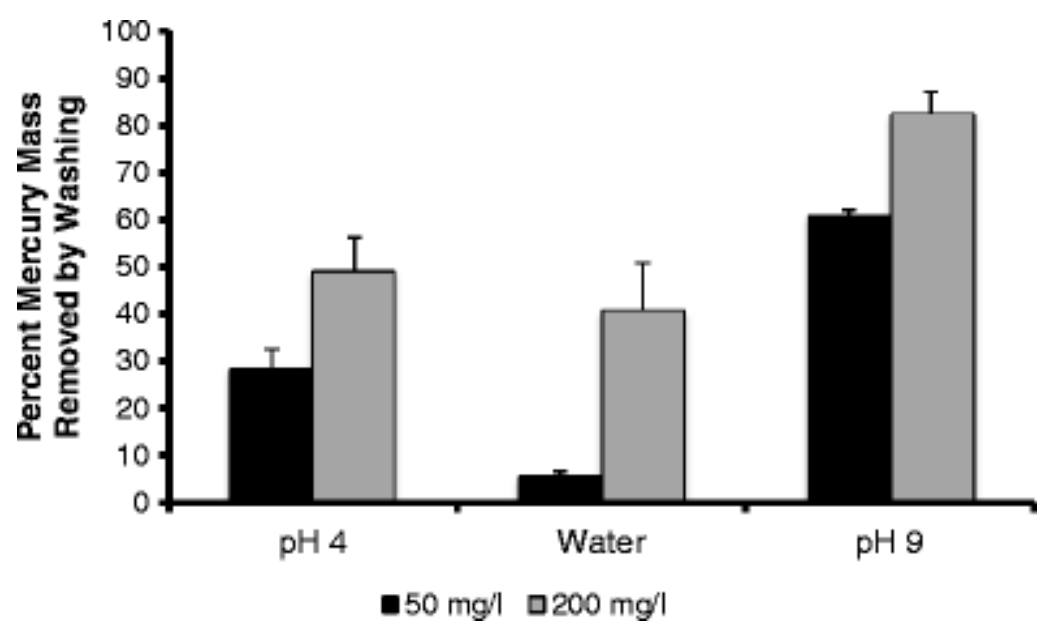


Fig. $3 \mathrm{Hg}$ resistance of strains E. coli K12 strains ZK2686 (wild-type) and ZK2687 (EPS mutant). a. Zones of inhibition for wild-type (filled) and mutant (open). Difference between strains was statistically significant ( $p$-value $\leq 0.05$, 2- way ANOVA). b. Hg disc inhibition test for strains E. coli MG1655 (wild type) and its mutant derivatives. Graph depicting zones of inhibition for strain (MG1655, filled diamond), biofilm super producer (TRMG1655[csrA::kan], filled square), colanic acid mutant (cpsE) of TRGM1655 with normal production of hexoseamine (strain DJ4, open triangle), and hexosamine mutant (pgaC) of TRGM1655 with normal production of colonic acid (strain TRXWMG $\triangle \mathrm{C}$, open square)

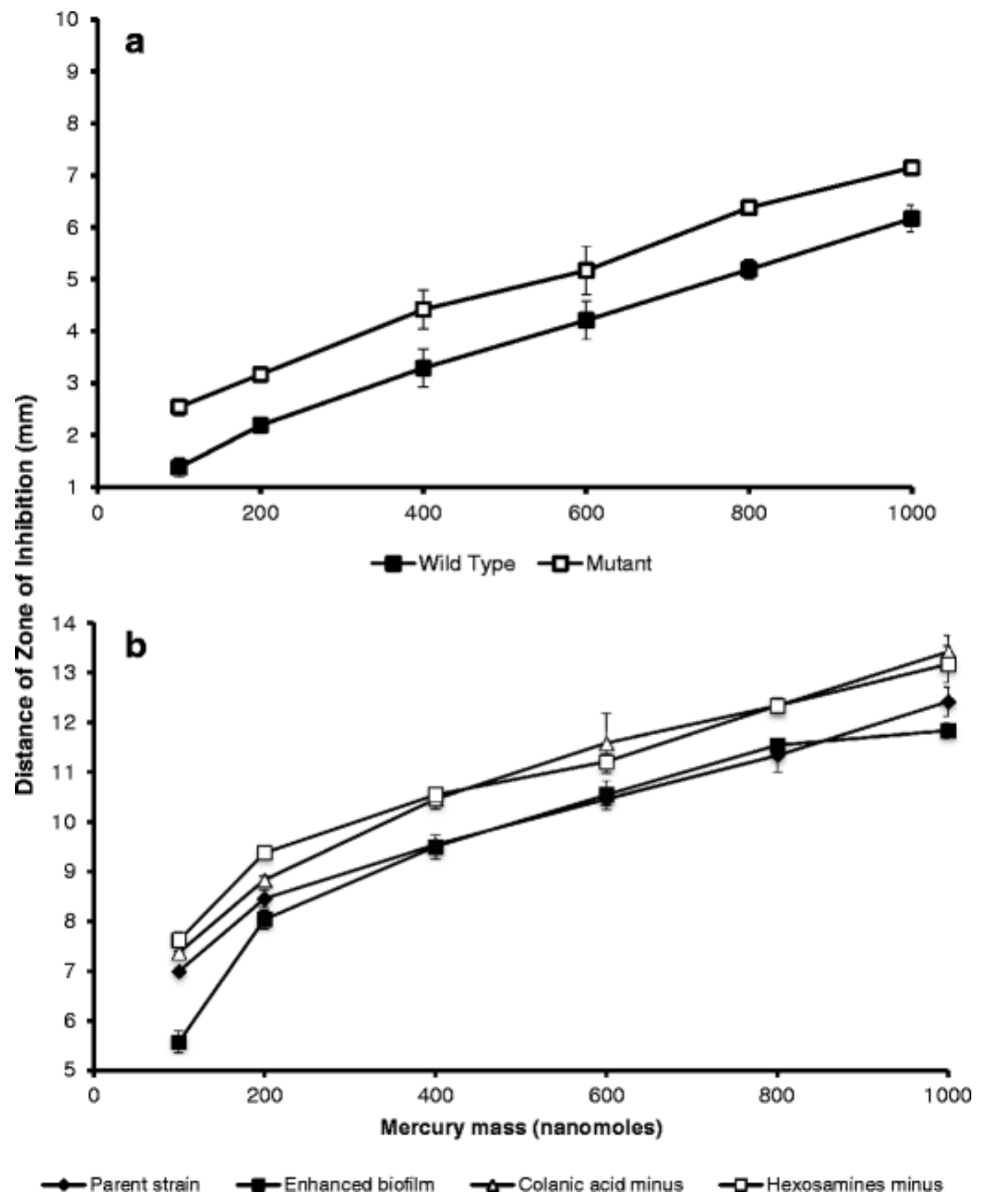


Table 1 Chemical properties of the EPS that were examined in this study

\begin{tabular}{|c|c|c|c|c|c|c|c|c|c|c|c|}
\hline EPS $^{1}$ & $\begin{array}{l}\text { Producing } \\
\text { strain }\end{array}$ & $\begin{array}{c}\text { MW } \\
\text { (Kda) }\end{array}$ & Ip & $\begin{array}{l}\text { Neutral } \\
\text { sugars } \\
(\% \mathrm{w} / \mathrm{w})\end{array}$ & $\begin{array}{c}\text { Uronic } \\
\text { acids } \\
(\% w / w)\end{array}$ & $\begin{array}{l}\text { Hexos- } \\
\text { amine } \\
(\% w / w)\end{array}$ & $\begin{array}{l}\text { Sulfates } \\
(\% w / w)\end{array}$ & $\begin{array}{l}\text { Proteins } \\
(\% w / w)\end{array}$ & $\begin{array}{c}\text { Sub- } \\
\text { stituents }\end{array}$ & $\begin{array}{l}\text { Metals } \\
\text { binding }\end{array}$ & $\begin{array}{c}\mathrm{Hg} \\
\text { sorption }^{2}\end{array}$ \\
\hline $\mathrm{RA} \mathrm{19}^{[18]}$ & Paracoccus sp. & $4.3 \times 10^{3}$ & 1.3 & 48 & 8 & & 29 & 3 & Acetate & $\begin{array}{c}\mathrm{Cu}^{2+}, \mathrm{Fe}^{2+}, \\
\mathrm{Ag}^{+}\end{array}$ & Yes \\
\hline Mo $203^{[18]}$ & $\begin{array}{c}\text { Alteromonas } \\
\text { sp. }\end{array}$ & $1.8 \times 10^{3}$ & 2.6 & 46 & 20 & & & 4 & & $\begin{array}{c}\mathrm{Cu}^{2+}, \mathrm{Fe}^{2+}, \\
\mathrm{Ag}^{+}\end{array}$ & Yes \\
\hline GG & Unknown & $9.7 \times 10^{2}$ & 4.2 & 100 & & & & & & $\mathrm{Cu}^{2+}, \mathrm{Pb}^{2+}$ & Yes \\
\hline$H E 800^{[9]}$ & $\begin{array}{c}\text { Vibrio } \\
\text { diabolicus }\end{array}$ & & & 2.5 & 32 & 33 & & 2.5 & & $\begin{array}{c}\mathrm{Cd}^{2+}, \mathrm{Ag}^{+} \\
\mathrm{Zn}^{2+}\end{array}$ & Yes \\
\hline$H Y D-1545^{[9]}$ & $\begin{array}{l}\text { Pseudoaltero } \\
\text {-monas sp. }\end{array}$ & $>10^{6}$ & & 51 & 34 & $\mathrm{Tr}$ & & & & & Yes \\
\hline
\end{tabular}

'EPS's from microbial mats in French Polynesian atolls are in bold and those from deep sea hydrothermal vents are italicized; each entry is followed by a reference where the isolation and properties of the EPS is described

${ }^{2}$ Results of this study 
Table 2 Uptake capacities $Q_{\max }$ and dissociation constants $K_{d}$ of $\mathrm{Hg}$ by marine exopolysaccharides

\begin{tabular}{ccc}
\hline EPS & $\mathbf{Q}_{\max }(\mathbf{m m o l} / \mathbf{g})$ & $\mathbf{K}_{\mathbf{d}}(\mathbf{m m o l} / \mathbf{L})$ \\
\hline RA 19 & $0.25 \pm 0.11$ & $1.41 \pm 0.74 \times 10^{-3}$ \\
Mo 203 & $0.19 \pm 0.03$ & $5.70 \pm 2.39 \times 10^{-4}$ \\
Mo 245 & $0.39 \pm 0.03$ & $1.05 \pm 0.27 \times 10^{-3}$ \\
GG & $0.10 \pm 0.05$ & $1.42 \pm 1.79 \times 10^{-4}$ \\
HE800 & $0.37 \pm 0.04$ & $1.52 \pm 7.46 \times 10^{-2}$ \\
HYD-1545 & $0.20 \pm 0.45$ & $1.37 \pm 0.27 \times 10^{-1}$ \\
MS 907 & $0.43 \pm 0.52$ & $2.98 \pm 0.03 \times 10^{-1}$ \\
\hline
\end{tabular}

